\title{
Vertical Flue Gas Heat Absorption System with Option for Fuel Drying
}

\author{
Edmunds Visockis ${ }^{1}$, Pēteris Vucenlazdāns ${ }^{1}$, Raimunds Šel̦egovskis ${ }^{2}$ \\ 1 - Rezekne Higher Education Institution, Faculty of Engineering, Latgale Sustainable Development \\ ResearchInstitute; e-mail:ems@inbox.lv \\ 2 - Latvia University of Agriculture, Faculty of Engineering, Institute of Agriculture Energetic
}

\begin{abstract}
The publication will describe research that produced vertical inglenook type innovative vertical flue gas heat absorption system with option for fuel drying. Innovative arrangement of smoke ducts will be developed for the flue gas heat absorption inglenook. The inglenook will be heating up in the bottom therefore the lower level of premises will be heated more efficiently and provide higher degree of comfort. Considering fire safety regulations above the inglenook 4 arches will be built for storing and drying firewood before burning.
\end{abstract}

Keywords: firewood drying, oven-couch, energy efficiency, microclimate of buildings.

\section{INTRODUCTION}

Usually there are two types of heating. The first is operating by small capacity during heating time without heat accumulator. The second is operating with considerably higher capacity, heating up heat accumulator and stops. Accumulated heat energy heats up interior of the building. Implementation of the first system is usually cheaper than the second. But exploitation costs of the second system are more profitable. Preparation of firewood bricks in right size is very important. For the first kind of heating rough size logs are recommended, because they must burn long time and give heat. Unfortunately also heat losses via flue gases are high. For the second kind of heating thin size logs are recommended, because they must burn fast and heat up accumulator. In short burning time with high temperature and capacity it is possible to produce more heat and decrease heat losses by flue gas. Considerable improvement of working conditions of heating system is possible by additional drying and pre-heating of firewood. That is easy to set on fire, is burning by high temperature, increases capacity of boiler for $10 \ldots 15 \%$. Regulations of fire safety must be kept carefully and solution has to be found to suitable use of heat energy of the boiler surface, which usually produces losses [1].

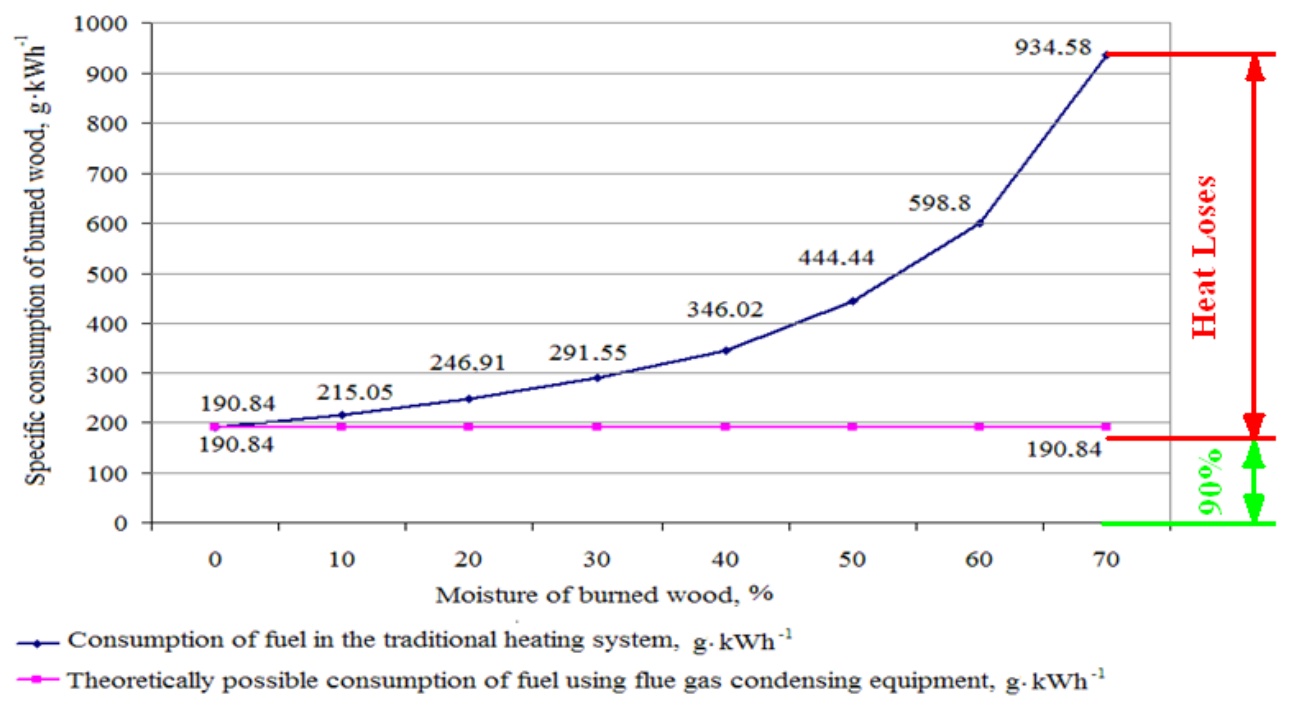

Fig.1.Dependence of the heat energy losses from the wood fuel moisture [1, 2]

When dry fuel is burnt in the heating equipment, efficiency factor of which is indicated in the technical passport for example as $90 \%$, the heat losses arising from the discharge of flue gas into atmosphere are amounting to $10 \%$. If this is moist fuel, thermal energy from the combustion process is used for its drying, and the latent thermal energy of the generated steam together with flue gas is discharged into atmosphere. In order the heating equipment to ensure a constant amount of the obtained thermal energy, the blue curve represents increase in consumption of fuel depending on the amount of moisture in the fuel (Fig 
1). This demonstrates that in order the heating equipment without condensation of flue gas and the steam latent heat recovery system to function with the specified efficiency factor and the fuel to be used economically, prior to combustion it should be sufficiently dried. The solution proposed in the publication relatively makes it possible to perform without using additional thermal energy, since in order to ensure for an individual optimum microclimate of the room to be heated, unnecessary evaporization of water during the winter can be avoided to maintain moisture appropriate for comfort in the atmosphere of the room to be heated.

\section{MATERIALS AND METHODS}

The firewood will be dried for about a month (each arch to be used for a week) thus reducing moisture content by $25-35 \%$ in the firewood which previously has been stored under a shelter outdoors till 5-10\% of moisture. This will significantly ease firing, improve quality and intensity of a burning process, shorten duration of the burning, will reduce firewood consumption and emissions of the flue gases, their temperature and amount of hazardous particles in them. It also will reduce possibility of condensate build up on the surfaces of the ducts and chimney, increase the coefficient of performance of the heating system etc. Humidity produced during drying process will be used to humidify air in the heated premises when due to freezing temperatures humidity in the fresh air introduced from outdoors is reduced and dropped below optimum of 45-55\%. The collected data will be processed using Excel software and the results of the scientific research will be shown in graphs.

Description of the construction of experimental object: the experimental object is located within the building to be heated in such manner as the ovencouch to function also as a partition wall between two rooms to be heated and both sides of the oven-couch to heat it. Monolithic concrete foundations were constructed. On these an oven-couch has been built from side-facing 400 clay furnace bricks, on which four arched shelves for additional drying of fuel have been built from 100 bricks. A mantel façade from 250 bricks has been built close by in compliance with fireprevention regulations. As a binding agent for ovencouch were used $400 \mathrm{~kg}$, for shelves $80 \mathrm{~kg}$, but for mantel façade $200 \mathrm{~kg}$ of sand-cement-lime mixture PM
Super. A steel fire furnace connected with oven-couch and the existing brick chimney was inserted in the mantel façade. Oven-couch is horizontally divided in two parts (see Fig. 2).

Working of the experimental object: open valves (2) and (3). Place the fuel into fire furnace (1) and set fire. Flue gases are mainly flowing through valve (2) to chimney (4) and warming it up for 5-10min. When the fuel has well caught fire and draught has become sufficiently strong, the valve (2) is closed. From fire furnace the hottest flue gases are flowing through flue gas shafts (5) of the lower part forward to the ovencouch end and more warming up its lower part. The more intensive infra-red radiation radiated from the oven-couch warms up the lower part of the room to be heated. It provides for a more even heat distribution and a more comfortable conditions in the room to be heated. At the oven-couch end flue gases are considerably cooled down and flow into flue gas shafts (6) of the upper part and dissipate a part of the remaining heat. When the fuel has fully burnt down, the valve (3) is closed and the oven-couch continuously releases the accumulated heat in the room. This solution fully complies with the fire safety requirements in order to firewood could be placed above the oven-couch on drying shelves(7) for additional drying before combustion. Shelves are divided into four parts. Fuel of each part is intended to be combusted approximately within one week and at once to be filled up again. In this way the fuel is intended to be subject to additional drying approximately for one month before incineration. Since upper portion of the oven-couch is considerably cooler than the lower one, drying of the fuel is predominantly ensured by the warm air accumulated in the upper part of the room and ventilated by its free flow. Moisture contained in the fuel is considerable reduced during the additional drying process. Such decision allows to use an existing chimney built from bricks, since notwithstanding high efficiency factor of the heating system due to which flue gas is cooled down to a comparatively low temperature, actually no condensate is developing and no stainless steel casing has to be inserted in the brick chimney, or no other heat-insulated steel chimney has to be built. From the fuel the dried out moisture contributes to more optimal microclimates of the rooms to be heated during the heating season, when the fresh outdoor air is cold and excessively dry. 


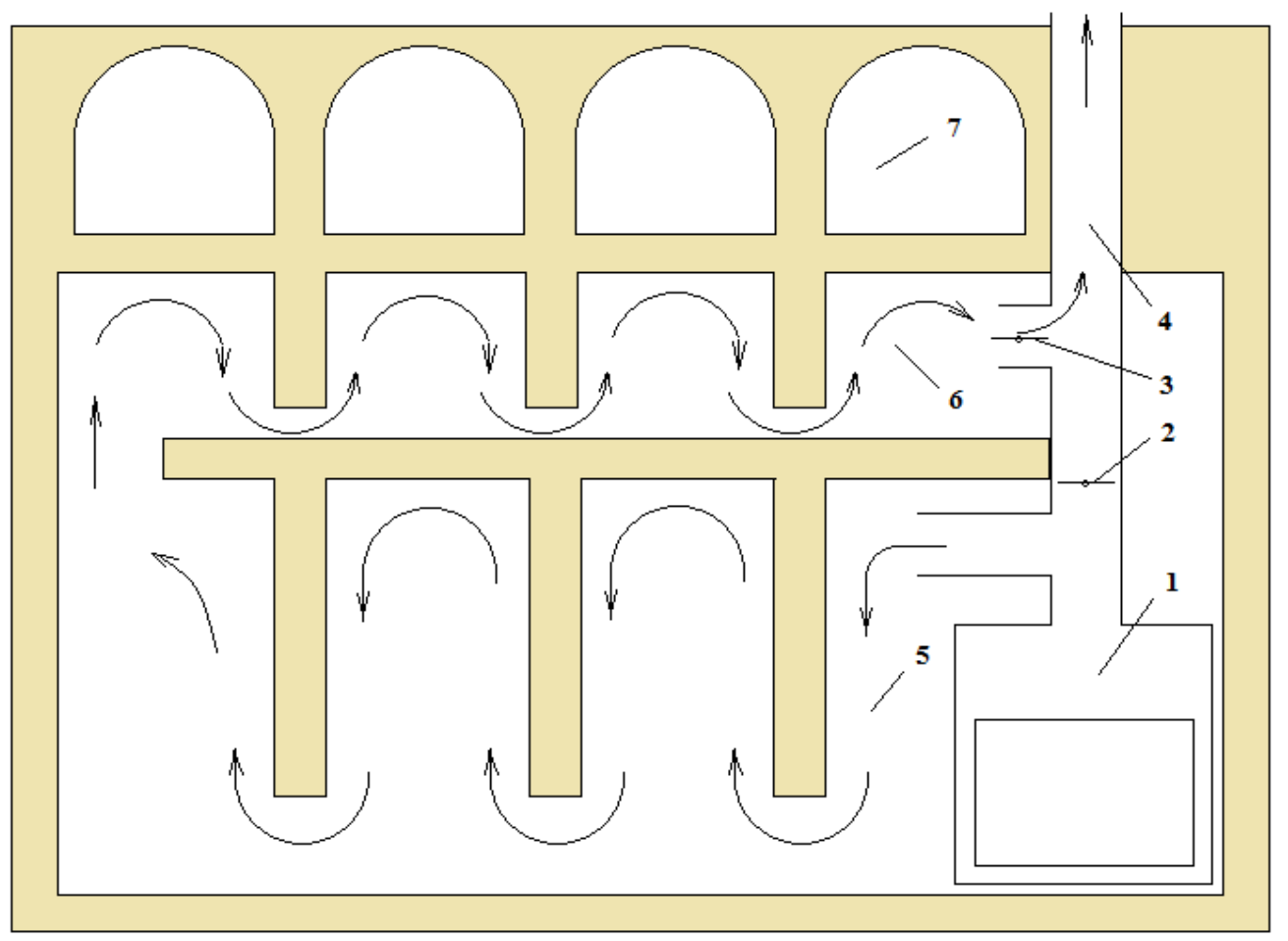

Fig. 2. The vertical flue gas heat absorption structure with the fuel additional drying option

1- furnace; 2- flue gas flow regulating valve to chimney or oven-couch; 3- oven-couch seal; 4- chimney, 5- forward shaft of the hottest ovencouch flue gas; 6- backward shaft of the coolest oven-couch flue gas; 7- additional drying shelves for fuel

Description of the experiment. In order to bring conditions as close as possible to the real situation, experiments were performed during the winter heating season each day from 1 February to 20 February 2013.

Each time $7 \mathrm{~kg}$ of different wood species with moisture $10 \%$ were inserted into the furnace. By means of an electronic multimeter the outdoor air temperature (average $-5^{\circ} \mathrm{C}$ ), the room air temperature, air temperature at inlet to the furnace, on flue gas pipe surface from the furnace and in flue pipe from the oven-couch to the chimney was detected. Experimental measurements were read off at intervals of 30 minutes, heating duration of 2 hours, duration of indication readings as 3 hours. Upon summary of data obtained in 20 repeated experimental measurements, average temperatures were calculated (see tab. 1), but for the resulting curves see Figures 3 and 4.

TABLE 1.

EXPERIMENTAL STUDIES OF THE OPERATION OF VERTICAL FLUE GAS HEAT ABSORPTION STRUCTURE

\begin{tabular}{|l|l|l|l|l|l|l|}
\hline \multirow{2}{*}{$\begin{array}{l}\text { Experiment } \\
\text { duration, min. }\end{array}$} & \multicolumn{2}{|l|}{ Average temperature, ${ }^{\circ} \mathrm{C}$} \\
\cline { 2 - 7 } & Indoor air & $\begin{array}{l}\text { Air inflow to } \\
\text { furnace }\end{array}$ & $\begin{array}{l}\text { Discharge of fuel } \\
\text { gas from furnace }\end{array}$ & $\begin{array}{l}\text { Discharge of } \\
\text { fuel gas from } \\
\text { oven-couch }\end{array}$ & $\begin{array}{l}\text { Oven-couch } \\
\text { lower part }\end{array}$ & $\begin{array}{l}\text { Oven-couch upper } \\
\text { part }\end{array}$ \\
\hline 0 & 18 & 18 & 18 & 18 & 18 & 18 \\
\hline 30 & 22 & 19 & 215 & 25 & 28 & 23 \\
\hline 60 & 24 & 20 & 230 & 28 & 32 & 25 \\
\hline 90 & 28 & 22 & 185 & 30 & 40 & 27 \\
\hline 120 & 28 & 22 & 125 & 29 & 40 & 27 \\
\hline 150 & 27 & - & - & - & 38 & 28 \\
\hline 180 & 27 & - & - & - & 37 & 28 \\
\hline
\end{tabular}

Description of data obtained in experimental studies of the operation of vertical flue gas heat absorption structure.

The data obtained resulting from experimental studies were entered into the Excel program by creating a Table 1, from which Figures 3 and 4 were obtained. Processing of the data obtained resulting from experiment was carried out using the Excel program. Distribution in energy is demonstrated by Fig. 4, representing the areas taken by the flue gas temperatures from the furnace and from the ovencouch. 
Visockis E., Vucenlazdāns P., Šel̦egovskis R. VERTICAL FLUE GAS HEAT ABSORPTION SYSTEM WITH OPTION FOR FUEL DRYING

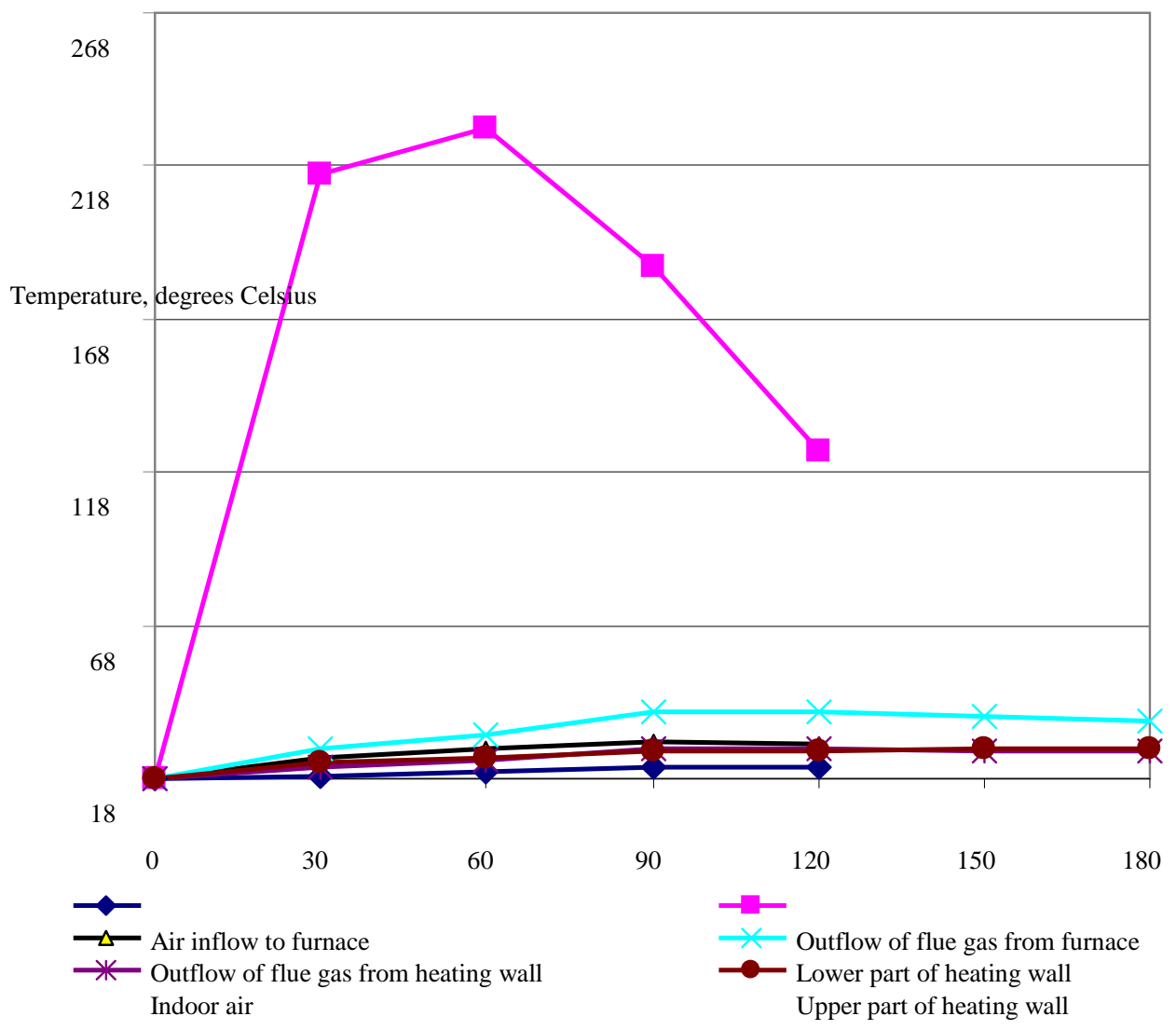

Fig.3. Average temperature of the operation of vertical flue gas heat absorption structure

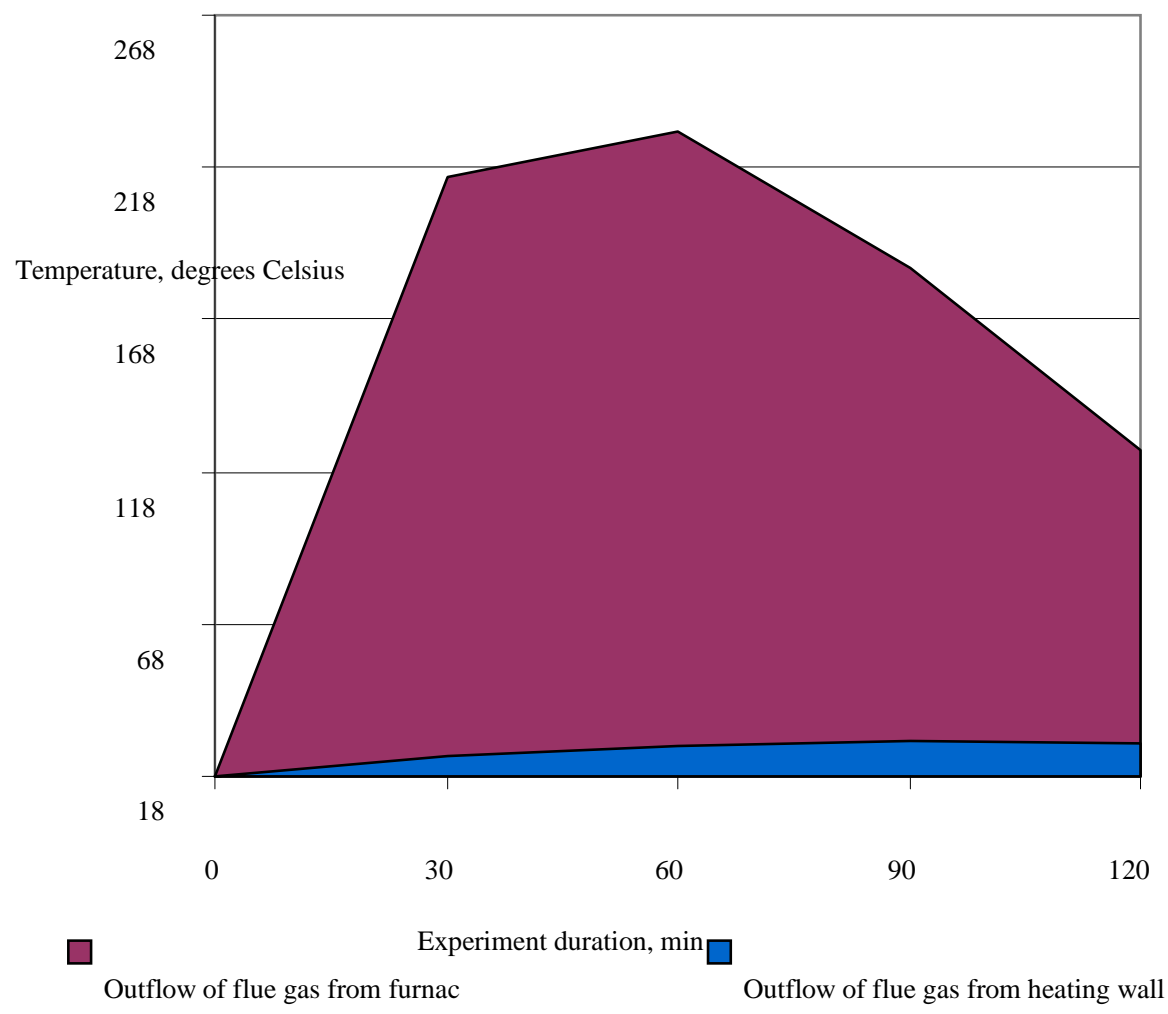

Fig. 4. The heat quantity recovered from flue gas as a result of the use of vertical flue gas heat absorption structure 
The claret field, filled by flow of the flue gas from the furnace to the oven-couch, pro rata indicates how much heat is removed from the flue gas and accumulated in building structures of the oven-couch. The blue field, filled by flow of the flue gas from the oven-couch to the chimney, pro rata indicates how much flue gas heat is discharged into atmosphere.

After comparison of sizes of the blue field and the claret field, a rough estimate can be made, how much amount of heat is taken and accumulated by the ovencouch. This improves efficiency of the heating system and increases overall efficiency factor exceeding nominal efficiency factor of the heat generator.

Calculation of efficiency for use of the flue gas heat in the oven-couch

In combustion of mixed wood with moisture content of $10 \%$, the maximum quantity of heat, which can be obtained from one $\mathrm{kg}$ of wood amounts to $\mathrm{Q}_{\mathrm{A}}=$ $18864 \mathrm{~kJ}^{*} \mathrm{~kg}^{-1}\left(4,65 \mathrm{kWh} \mathrm{kg}^{-1}\right)$ heat, taking into account gross calorific value or $\mathrm{Q}_{\mathrm{Z}}=16740 \mathrm{~kJ} * \mathrm{~kg}$ ${ }^{1}\left(5,24 \mathrm{kWh}^{*} \mathrm{~kg}^{-1}\right)$ by consideration of net calorific value $[3,4]$.

Having regard of the composition of such wood it is possible to determine the composition and the amount of flue gas.
Estimated wood composition by mass percentage [5] (by consideration of moisture content $\mathrm{W}=10 \%$ ) is as follows: $\mathrm{A}=1.3 \%, \mathrm{C}=43.9 \%, \mathrm{H}=5.5 \%, \mathrm{O}=39.3 \%$.

In theory, the air required for burning per $1 \mathrm{~kg}$ of wood subject to combustion:

$$
V^{0}=0,0889 * C+0,266 H-0,033 * O=4,07 m^{3} * k^{-1}
$$

Composition of flue gas generated through combustion of $1 \mathrm{~kg}$ wood at the excess air factor $\alpha=1.3$, shall be composed of:

- the amount of carbon dioxide:

$$
V_{\text {CO2 }}=0,0187 * C=0,83 m^{3} * k g^{-1}
$$

- theoretical amount of nitrogen:

$$
V_{N 2}^{0}=0,79 * V^{0}=3,21 \mathrm{~m}^{3} * \mathrm{~kg}^{-1} \text {; }
$$

- the water vapour amount:

$V_{H \mathbf{z O}}=0,111 * H+0,0124 * W+0,0161 * \alpha * V^{0}=0,82 \mathrm{~m}^{\mathrm{a}} * \mathrm{~kg}^{-1}$.

Total amount of flue gas from $\mathrm{M}=7 \mathrm{~kg}$ wood:
According to experimentally obtained data found in Table 1 , the average flue gas temperature at outflow from the furnace reaches $\mathrm{t}_{\mathrm{mk}}=154.6{ }^{0} \mathrm{C}$, at outflow from the oven-couch reaches $\mathrm{t}_{\mathrm{ms}}=26{ }^{0} \mathrm{C}$.

$$
V_{d}=M *\left(V_{C O \mathbf{2}}+V_{N \mathbf{2}}^{0}+V_{H \mathbf{2} O}+(\alpha-1) * V^{0}\right)=42.5 m^{3} .
$$

Flue gas heat, when leaving the furnace consists of heat $\mathrm{H}_{\mathrm{d} 154}{ }^{0}$ contained in the combustion reaction products and heat content of the air getting into flue gas $\mathrm{H}_{\mathrm{g} 154}$ :

$$
H_{d 154}^{0}=\left(c_{C O \mathbf{2}}^{*} * V_{C O \mathbf{2}}+c_{N \mathbf{2}}^{*} * V_{N \mathbf{2}}^{0}+c_{H \mathbf{2} O}^{*} * V_{H \mathbf{2} O}\right) * t_{m k}=1056,1 \mathrm{~kJ} * \mathrm{~m}^{-\mathbf{3}},
$$

where: c' ${ }_{\mathrm{CO} 2}, \mathrm{c}_{\mathrm{N} 2}, \mathrm{c}_{\mathrm{H} 2 \mathrm{O}}$ - according to $\mathrm{CO}_{2}, \mathrm{~N}_{2}$ and water vapour calorific capacity at a given temperature $\mathrm{t}_{\mathrm{mk}}, \mathrm{kJ}^{*} \mathrm{~m}^{-3} * 0 \mathrm{C}^{-1}$.

$H_{g 154}=c_{g}^{*} * V^{0} * t_{m k}=832,4 k J * m^{-3}$,

where: $\mathrm{c}_{\mathrm{g}}-$ air calorific capacity at a given temperature $\mathrm{t}_{\mathrm{mk}}, \mathrm{kJ} * \mathrm{~m}^{-3} *^{0} \mathrm{C}^{-1}$.

Heat quantity $\mathrm{Q}_{\mathrm{dk}}$ contained in the flue gas outflow from the furnace with average temperature of 154.6 ${ }^{0} \mathrm{C}$, through combustion of $7 \mathrm{~kg}$ wood, shall be:

$$
\begin{aligned}
& Q_{d k}=V_{d} *\left(H_{d 154}^{0}+(\alpha-1) * H_{g 154}\right)=55497 \mathrm{~kJ} \quad \text { into flue gas } \mathrm{H}_{\mathrm{g} 26} \text { : } \\
& H_{d 26}^{0}=\left(c_{C O 2}^{\circ} * V_{C O 2}+c_{N 2}^{\circ} * V_{N 2}^{0}+c_{H 2 O}^{\circ} * V_{H 2 O}\right) * t_{m s}=174,7 \mathrm{~kJ} * m^{-3} \\
& H_{g 26}=c_{g}^{*} * V^{0} * t_{m s}=139,8 \mathrm{~kJ} * \mathrm{~m}^{-\mathbf{3}} \text {. }
\end{aligned}
$$

Heat quantity $\mathrm{Q}_{\mathrm{dm}}$ contained in the flue gas outflow from the oven-couch at combustion of $7 \mathrm{~kg}$ wood, shall be:

Thus, the amount of heat that has been recovered from the flue gas in the oven-couch can be calculated as:

$$
Q_{d m}=V_{d} *\left(H_{d 26}^{0}+(\alpha-1) * H_{g 26}\right)=9207,2 \mathrm{~kJ} Q_{m}=Q_{d k}-Q_{d m}=46289,8 \mathrm{~kJ} .
$$

Portion of the amount of heat, which is recovered from flue gas through the built oven-couch, by 
applying to total heat to be obtained in the combustion process, shall be as follows:

- applying to the gross calorific value:

$Q_{i a}=Q_{m} / M * Q_{A} * 100 \%=46289,8 / 7 * 18864 * 100 \%=35 \%$

- applying to the net calorific value:

$Q_{i a}=Q_{m} / M * Q_{z} * 100 \%={ }^{46289,8} / 7 * 16740 * 100 \%=39,5 \%$

Portion of the heat recovered from total heat possessed by flue gas at the furnace outlet shall be:

$$
Q_{a t}=Q_{m} / Q_{d k} * 100 \%=46289,8 / 55497 * 100 \%=83,4 \%
$$

Definitely, if more heat is removed in the boiler, then the temperature of flue gas at the furnace outlet will also be reduced, efficiency factor of the boiler itself will increase and the impact of oven-couch in improving of the efficiency will be reduced. Flue gas temperature over $100^{\circ} \mathrm{C}$ at the boiler outlet permanently leads to inadequate thermal loss. For steel boiler the flue gas temperature along the surfaces may not be reduced below $60{ }^{0} \mathrm{C}$, to avoid formation of condensate, which contributes to corrosion. This means that for the boiler these temperatures are the extreme minimum limit. By reducing the flue gas temperature close to the ambient temperature (such as in the experimental object at intensive combustion the outlet temperature from the oven-couch does not exceed $30^{\circ} \mathrm{C}$ ) a substantial amount of heat is recovered. This process may be executed by building additional structures with the surfaces made from materials to which the condensate is not dangerous.

\section{CONCLUSIONS}

1. The built experimental oven-couch significantly increases the heat using efficiency, by recovering the flue gas- contained heat at furnace outlet of the flue gas heat generator. The amount of heat dissipated by flue gas at given circumstances for the existing structure constitutes $35 \%$ of the maximum available heat with consideration of the fuel gross calorific value, or $39.5 \%$ with consideration of the net calorific value.

2. Experiments demonstrate that a very high proportion of thermal loss is the loss with fuel gas, which temperature is above the ambient temperature. Cooling down the fuel gas to the temperature close to the ambient temperature can significantly improve overall efficiency of the heating system.

3. Construction of additional structures for recovery of the flue gas heat, allows to maintain a sufficiently high temperature in the boiler to prevent development of corrosion-inducing condensate and to stimulate the burning intensity and completeness of combustion.

4. When making analysis of the experimental data obtained in the built heat recovery system, it is estimated that through such a system it is possible to recover at the furnace outlet approximately $83 \%$ from the heat contained in the flue gas, using the given conditions. This proportion is affected by the flue gas composition, the flow conditions and the initial temperatures.

\section{ACKNOWLEDGMENTS}

To the Association "EKOtehnologijas" for building of the experimental object and rooms used for the experimental research.

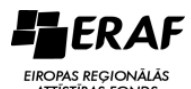

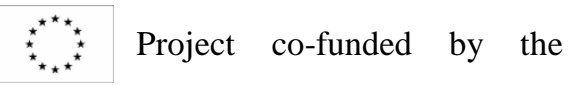
European Regional Development Fund

"Hybrid technologies for increasing efficiency of efficiency of power systems, purification of emissions and mitigation of climate changes", Project Agreement No. 2010/0267/2DP/2.1.1.1.0. /10/APIA/VIAA/169

\section{REFERENCES}

[1] Visockis E., Vucenlazdans P., Ansone V., Morozova I.RESEARCH ON POSSIBILITIES FOR DECREASING HEAT LOSSES IN BUILDINGS International scientific publication of conference Research For Rural development. Latvia University of Agriculture, 2011, Jelgava, 342.-347.p.

[2] Visockis E. Grīdas apsilde ar dūmgāzēm (in Latvian Floor heating the waste gases). Promotion thesis. Latvia University of Agriculture, 2008, Jelgava, 130p.

[3] Dolacis J., Tomsons E., Hrols J. Kurināmās koksnes salīdzinājums ar citiem kurināmā veidiem (in Latvian Fuel wood comparison with other types of fuel). //Environment. Technology. Resources. Proceedings of the international scientific conference. Rezekne. 2003.

[4] R.Šel̦egovskis. Sausa kokšķelda - energoapgādes risinājums (in Latvian - Dry woodchips as the power supply solutions). www.mezasiltums.lv/lv/sausakokskelda-energoapgades-risinajums. - skat. 11.02.2013.

[5] J. Nagla., P. Saveljevs, A.Cars. Siltumtehniskie aprēķini piemēros (in Latvian - Calorific calculations in examples). R.: Zvaigzne, 1982. - 310 lpp. 